\title{
Isolation and Identification of Endophytic Fungi of Urena lobata L. Cultivated in Amazon
}

\author{
Carla Coelho Ferreira ${ }^{1}$, Henrique dos Santos Pereira ${ }^{1}$, Albejamere Pereira de Castro ${ }^{1}$, \\ Pedro de Queiroz Costa Neto ${ }^{1} \&$ Kelven Wladie dos Santos Almeida Coelho ${ }^{1}$ \\ ${ }^{1}$ Federal University of Amazonas, Manaus, Amazonas, Brazil \\ Correspondence: Carla Coelho Ferreira, Federal University of Amazonas, Manaus, Amazonas, Brazil. E-mail: \\ carlacoelhofigueiredo@gmail.com
}

Received: June 30, 2018

doi:10.5539/jas.v10n10p316

\author{
Accepted: August 1, $2018 \quad$ Online Published: September 15, 2018 \\ URL: https://doi.org/10.5539/jas.v10n10p316
}

\begin{abstract}
Fiber of Urena lobata L. (Caesar weed or Malva) has been produced from plants cultivated in floodplain areas of Brazilian Amazonas state since 1970s. Plants must be harvested before flooding and because of such a short cultivation season plants never reach fructification. Thus, local farmers depend on acquiring seeds collected in areas of spontaneous occurrence in drylands to sow their crop fields each year. This scenario might change, as this species is gaining socioeconomic important and there is interest in the development of cropping systems for seed production on a commercial scale. The objective of this study was to investigate the occurrence of endophytic fungi in $U$. lobata, evaluating the influence of the plant organ (leaf and seed) and farming site (two experimental fields of seed production: Manaus and Anori municipalities), once endophytic interaction can be beneficial or become harmful to the plants. The frequency and degree of colonization, Shannon-Weaver and Simpson diversity and Pielou uniformity indexes and the dominance component curve were calculated. The occurring genus were: Phomopsis, Colletotrichum, Fusarium, Pestalotiopsis, Curvularia and Cochliobolus. The greatest diversity and richness of fungi was found in Manaus site with high colonization present in the leaves. The genus Curvularia and Fusarium presented preference for seeds while Colletotrichum was more frequent in leaves. The similarity was greater between plant organs than between the farming sites, which indicates that the coevolution of these fungi and its host has resulted in a balanced mutual or antagonistic interaction (Crane \& Acuna, 1945; Souza, 2012).
\end{abstract}

Keywords: Caesar weed, diversity, endophyte, leave, seed

\section{Introduction}

Caesar weed is widely distributed in the tropical and subtropical regions (Crane \& Acuna, 1945; Homma, 1998). It is considered worldwide a spontaneous plant that causes damages by competition with commercial crops. Nevertheless, the plant has been cultivated forits light, soft, silky and very flexible fiber, which is mainly used for the making of burlap bags for the export of agricultural products such as coffee, other textile products and handcrafts (Crane \& Acuna, 1945; Souza, 2012).

In Amazonas state, Malva is cultivated by traditional family farmers exclusively for fiber production in lowland environments, next to Amazon river channel. Due to the limitations of these cropping sites caused by seasonal flooding, plants are harvested before completing their life cycles and produce seeds (Souza, 2012; Bentes, Pereira, Mendes, Castro, \& Cunha, 2017).

Thus, Amazonian farmers depend on the seeds gathered by seed collectors of the neighbor State of Pará. These spontaneous seeds are purchased and distributed to fiber floodplain farmers by the Amazonas State Secretariat of Rural Production (SEPROR/AM) or by the textile industries. Often, offered quantities do not supply the demand, causing a reduction in fiber production due to the lack of this critical input (Souza, 2012; Bentes et al., 2017).

This critical situation of the Malva production chain has gained the attention of the research agencies and there are currently projects in progress to provide technical and agronomic information for the implantation of seed production fields in the State of Amazonas. As observed to have occurred with other native species, when an exploited wild species become economically important, the induction of species' management and domestication 
processes result in the expansion of supply, products of better quality and lower prices, benefiting consumers and producers (Homma, 2012).

However, the domestication process may cause alterations in the community of microorganisms associated with the crop, favoring plants susceptibility to pests and diseases directly, inducing a possible pathogenicity of these microorganisms once endophytes, or decreasing the capacity of defense of the plant for which endophytic fungi play an important role (Paterniani, 2001).

This is due to endophytic fungi can produce bioactive compounds capable of acting as a biocontrollers. They may have anticancer, antimicrobial and insecticide activity, be plant growth promoters and promote resistance to diseases, and therefore, they are active agents in phytoremediation (Sudha, Govindaraj, Kathirvelu, Al-Dhabi, \& Duraipandiyan, 2016).

Research related to the identification of the biodiversity of microorganisms associated with plant species improves knowledge about patterns of occurrence and distribution of biodiversity, important information for the planning of biodiversity conservation strategies. In addition, they represent a great opportunity to obtain fungi with differentiated potentials for scientific research and use in biotechnology and industry (Vieira, F. Silva, W. Silva, Cavalcanti, \& Lima, 2012). This is an area that needs to advance because there are few studies of isolated compounds from endophytic fungi of Amazonian plants (Carvalho, Paixão, Dolabela, P. Marinho, \& A. Marinho, 2016). In such perspective, the objective of this work was to investigate the influence of the plant organ and the cropping site on patterns of occurrence and diversityof endophytic fungi in cultivatedUrena lobata.

\section{Material and Methods}

\subsection{Place of Study}

The study was conducted in two seed production experimental fields in the State of Amazonas, in Brazilian Amazon region. The first one is located at the Experimental Farm of the Federal University of Amazonas (UFAM), at Km 38 of the BR-174 highway with coordinates $2^{\circ} 38^{\prime} 57.6^{\prime \prime} \mathrm{S}$ and $60^{\circ} 3^{\prime} 11^{\prime \prime} \mathrm{W}$, with an agricultural history of cassava cropping during three consecutive years in the period prior to the implantation of Malva in May of 2015. The other field was implanted in November of 2015, in an area of secondary forest in cattle ranch whose owner was interested in Malva seed production for commerce, located in the municipality of Anori, Anori-Mato Grosso road, $\mathrm{Km} 15$, left margin, with coordinates $03^{\circ} 36^{\prime} 57.8^{\prime \prime} \mathrm{S}$ and $61^{\circ} 40^{\prime} 30.58^{\prime \prime} \mathrm{W}$. The climate is the same in both locations, tropical humid, according to a classification of Koppen, with an average annual temperature of $25^{\circ} \mathrm{C}$ and a dry season between June and August, high rainfall (2,050 to 2,650 mm per year) and relative air humidity ranging from 85 to $90 \%$ (Martins, Ferreira, Curi, Vitorino, \& Silva, 2006).

The two fields were implanted using seeds from the municipality of Capitão-Poço (Pará state). Seeding was performed after seed dormancy break. Roughing and prune operations were carried out when the plants reached $30 \mathrm{~cm}$ and $100 \mathrm{~cm}$, respectively. Two plants were kept per pit with row-spacing of $1.5 \mathrm{~m}$ and spacing of $0.5 \mathrm{~m}$ between plants.

Leaves of the middle third and seed of the apex of 20 plants of each cultivation site were collected in the seed harvesting period, at the end of October of 2016. The material was sent to the Laboratory of Bioactive Principles of Microbial Origin of the Faculty of Agrarian Sciences of Federal University of Amazonas (FCA-UFAM) for the isolation of endophytic fungi.

\subsection{Isolation of Endophytic Fungi}

The material was subjected to surface disinfestation by immersion in ethanol $(70 \%)$ for one minute, $2.5 \%$ sodium hypochlorite for two minutes, $70 \%$ ethanol for 30 seconds and two washes in sterilized distilled water for one minute each (Pereira, Azevedo, \& Petrini, 1993). To confirm the effectiveness of the disinfection process, $100 \mu \mathrm{L}$ of the water used in the last wash in Potato-Dextrose-Agar (BDA, pH 6.8) culture medium was stained.

From each plant of each site, six seeds and six fragments with $0.3 \mathrm{~cm}^{2}$ of leaf limbus were deposited under aseptic conditions in Petri dishes (totaling 12 fragments per plate) with BDA culture medium supplemented with antibiotic chloramphenicol $\left(100 \mu \mathrm{g} / \mathrm{mL}^{-1}\right)$ to inhibit bacterial growth.

As plates were incubated at $18{ }^{\circ} \mathrm{C}$ and observed daily for up to 14 days. As emergent colonies were purified and preserved in BDA for later identification (Vieira et al., 2011). The fungi of the genus Phomopsis were transferred to agar-oat culture medium (AA, $\mathrm{pH}$ 6.8) and submitted to 24-hour photoperiod to induce sporulation (Nozaki, Camargo, \& Barreto, 2004). 


\subsection{Identification of Endophytic Fungi}

The fungi that presented the sporulation in culture conditions were identified in level of genus through the literature (Ellis, 1971; Bernett \& Hunter, 1972; Sutton, 1980) based on the macroscopic characteristics of the colonies - color, appearance, consistency, presence of pigment, etc., and microscopic characteristicsmorphology of somatic and reproductive structures, through the observation of slides with fragments of fungus structures under optical microscope. According to the analyzed characteristics, the isolates were grouped into morphotypes within each genus (Banhos et al., 2008; Magalhães, Missagia, F. Costa, \& M. Costa, 2008). For the greater richness of details of the fungi morphological structures, micro cultures were carried out.

\subsection{Statistical Analysis}

The frequency of colonization (FC\%) was calculated with the formula below (Petrini, Sieber, Toti, \& Viret, 1992):

$$
F C \%=\frac{\text { Total number of fragments with one or more isolates }}{\text { Total of isolates of the sample }} \times 100
$$

The degree of colonization was calculated by the formula:

$$
G C \%=\frac{\text { Number of isolates }}{\text { Plant }} \times 100
$$

To compare the communities of endophytic fungi in $U$. lobata, we evaluated the similarity between plant organs (leaf and seed) and cropping sites (Manaus and Anori) according to the morphotypes identified using Jaccard-JI index (Magurran, 1998). The cluster analysis of morphotype data was performed by the Ward's method.

To represent diversity, the Simpson, Shannon and Pielou indexes were calculated for both genus and morphotypes. The curve of the dominance component of the morphotype diversity of endophytic fungi isolated (Odum, 1983) was ploted.

The colonization degree data were subjected to analysis of variance by the F test. All data were analyzed and graphically represented by Paleontological STatistics (PAST) Version 3.14 (Hammer, Harper, \& Ryan, 2001).

\section{Results}

The frequency of colonization by endophytic fungi in Malvawas $85.7 \%$, with $24.2 \%$ in Manaus leaves; $21.9 \%$ in Manaus seeds; $23.8 \%$ in Anori leaves and $15.8 \%$ in Anori seeds. No microorganisms were observed in the surface disinfection control, indicating that the isolation method was efficient.

Six hundred and nineteen endophytic fungi were isolated from 240 leaf fragments and 240 mallow seeds. Of these, $24.88 \%$ were not identified because they did not present reproductive structures. Those that presented reproduction structure were identified and grouped into morphotypes according to macro and microscopic characteristics.

Six genus were identified, being Phomopsis, Colletotrichum and Fusarium the most frequent, and Pestalotiopsis, Curvularia and Cochliobolus less frequent. The composition of endophytic fungi differed between plant organs and between cultivation sites, with the highest leaf richness in Manaus (Table 1).

Table 1. Endophytic fungi associated with leaves and seeds of Urena lobata cultivated in Manaus and Anori,

\begin{tabular}{|c|c|c|c|c|c|c|c|c|}
\hline \multirow{2}{*}{ Genus } & \multicolumn{2}{|c|}{ Leaf from Manaus } & \multicolumn{2}{|c|}{ Seed from Manaus } & \multicolumn{2}{|c|}{ Leaf from Anori } & \multicolumn{2}{|c|}{ Seed from Anori } \\
\hline & Isolates & Morphotypes & Isolates & Morphotypes & Isolates & Morphotypes & Isolates & Morphotypes \\
\hline Phomopsis & 125 & 55 & 44 & 26 & 24 & 16 & 6 & 6 \\
\hline Colletotrichum & 65 & 20 & 2 & 2 & 80 & 28 & 3 & 3 \\
\hline Fusarium & 2 & 2 & 31 & 18 & 2 & 2 & 46 & 18 \\
\hline Pestalotopsis & 4 & 4 & 17 & 11 & 0 & 0 & 0 & 0 \\
\hline Curvularia & & & 5 & 1 & & & 4 & 1 \\
\hline Cochliobolus & & & & & 1 & 1 & & \\
\hline Total ( $\mathrm{S}=$ richness $)$ & & 81 & - & 58 & - & 47 & - & 28 \\
\hline
\end{tabular}
municipalities of the State of Amazonas

It was possible to observe preference of genus of endophytic fungi by the type of plant organ and cropping site. Curvularia occured exclusivelyin seeds, whereas Pestalotiopsis occurred only in Manaus, and Cochliobolus only 
in Anori. Colletotrichum was predominant in leaf and Fusarium in seed (Table 1), resulting in similarity between plant organs greater than between sites (Figure 1).

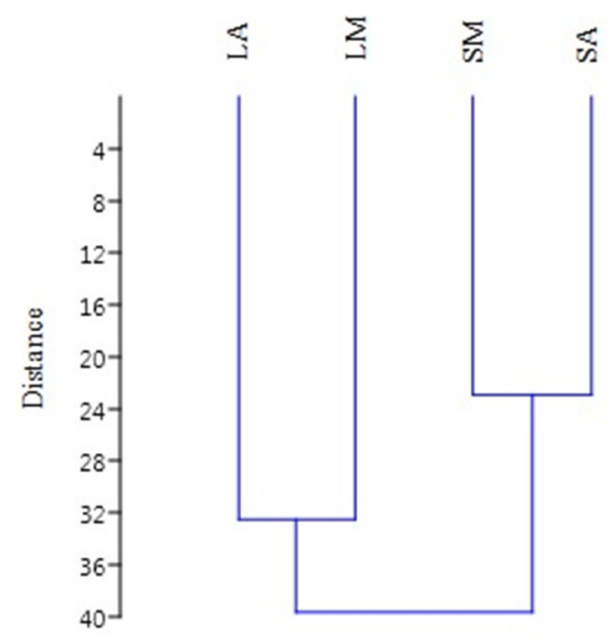

Figure 1. Dendrograms highlighting the relationship between the morphotypes of endophytic fungi communities in plant organs and Urena lobatacultivated at two locations in Amazonas

Note. $\mathrm{F}=$ Leaf; $\mathrm{S}=$ seed; $\mathrm{M}=$ Manaus; $\mathrm{A}=$ Anori.

The similarity for morphotypes was very low, that is, the great majority of the morphotypes were unique in each locality and plant organ. The highest number of common morphotypes was found between the seeds of Manaus and Anori (Table 2).

Table 2. Jaccard similarity index for endophytic fungus morphotypes observed among plant tissues of Urena lobata L. cultivated at two locations in Amazonas

\begin{tabular}{lllll}
\hline & LM & SM & LA & SA \\
\hline LM & - & & & \\
SM & 0.02 & - & & \\
LA & 0.03 & 0.01 & - & - \\
SA & 0.00 & 0.05 & 0.03 & - \\
\hline
\end{tabular}

Note. $\mathrm{F}=$ Leaf; $\mathrm{S}=$ seed; $\mathrm{M}=$ Manaus; $\mathrm{A}=$ Anori.

By the analysis of variance, both factors (plant organ and crop site) had significant effects on the degree of colonization of endophytic fungi in Malva. The interaction of these factors was not significant (Table 3). The colonization was higher in the leaves than in the seeds, independently of the cropping site (Figure 2); and higher in Manaus than in Anori, regardless of the type of plant organ (Figure 3).

Table 3. Analysis of the degree of colonization of endophytic fungi in the leaves and seeds of Urena lobata cultivated in the municipalities of Manaus and Anori in the State of Amazonas

\begin{tabular}{llllll}
\hline Source of variation & Sum of squares & Degrees of freedom & Mean Square & F & $\mathrm{p}$ \\
\hline Local & 10305.8 & 1 & 10305.8 & 44.22 & $3.98 \mathrm{E}-09$ \\
Organ & 3564.45 & 1 & 3564.45 & 15.3 & 0.0001984 \\
Interaction & 101.25 & 1 & 101.25 & 0.4345 & 0.5118 \\
Error & 17710.5 & 76 & 233.033 & & \\
Total & 31682 & 79 & & & \\
\hline
\end{tabular}




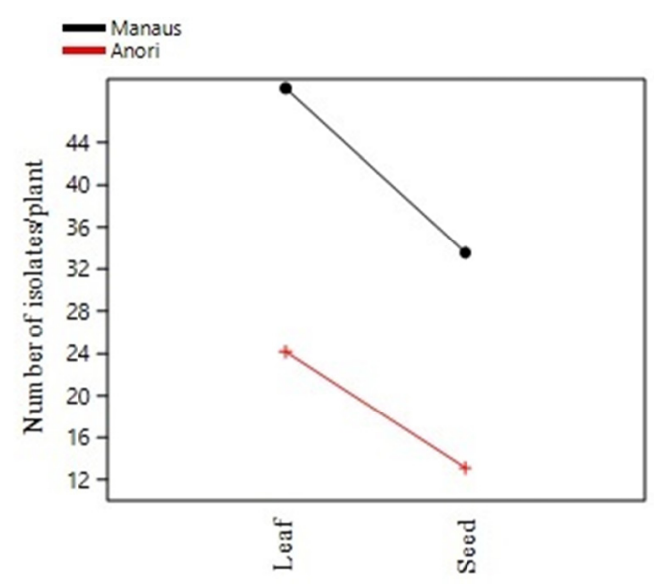

Figure 2. Degree of colonization of endophytic fungi in plant organs of Urena lobata cultivated in Amazonas

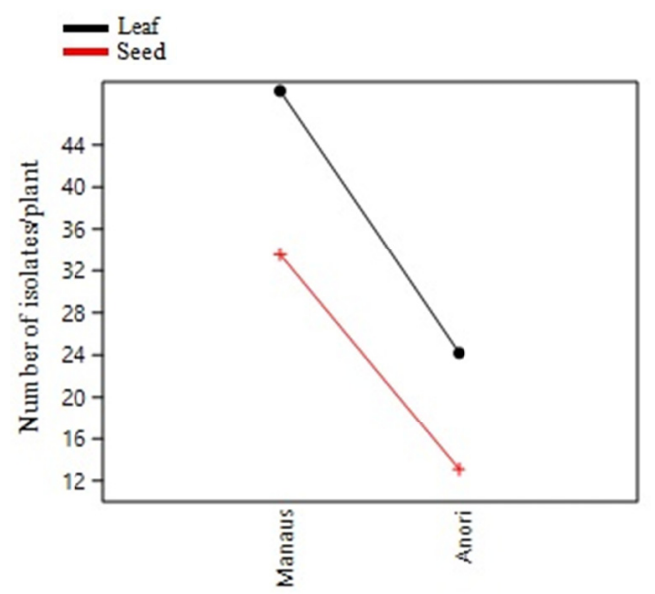

Figure 3. Degree of colonization of endophytic fungi of Urena lobatacultivated at two locations in Amazonas

The calculated diversity indexes indicate that the community of endophytic fungi associated with malva of Manaus, both in leaves and seeds, is more diverse when compared to Anori (Table 4).

Table 4. Diversity indexes calculated for communities of endophytic fungi isolated from leaves and seeds of Urena lobata cultivated at two locations in Amazonas

\begin{tabular}{|c|c|c|c|c|c|c|}
\hline \multirow{2}{*}{ Samples } & \multicolumn{2}{|c|}{ Shannon-Weaver (H') } & \multicolumn{2}{|c|}{ Inverse simpson (1/D) } & \multicolumn{2}{|c|}{ Pileou (e) } \\
\hline & Genus & Morphotype & Genus & Morphotype & Genus & Morphotype \\
\hline Leaf from Manaus & 0.8 & 3.9 & 1.9 & 21.2 & 1.3 & 2.0 \\
\hline Seed from Manaus & 1.3 & 3.9 & 3.0 & 38.1 & 1.8 & 2.2 \\
\hline Leaf from Anori & 0.6 & 3.3 & 1.6 & 13.7 & 1.0 & 1.9 \\
\hline Seed from Anori & 0.8 & 2.6 & 1.6 & 11.1 & 1.4 & 2.0 \\
\hline
\end{tabular}

Due to the dominance component of the morphotypes diversity of the isolated endophytic fungi, it is possible to perceive the great diversity of morphotypes and that, in general, these are represented by few individuals. It is also possible to verify that there was a reduced number of dominant morphotypes, containing a larger number of individuals (Figure 4). 


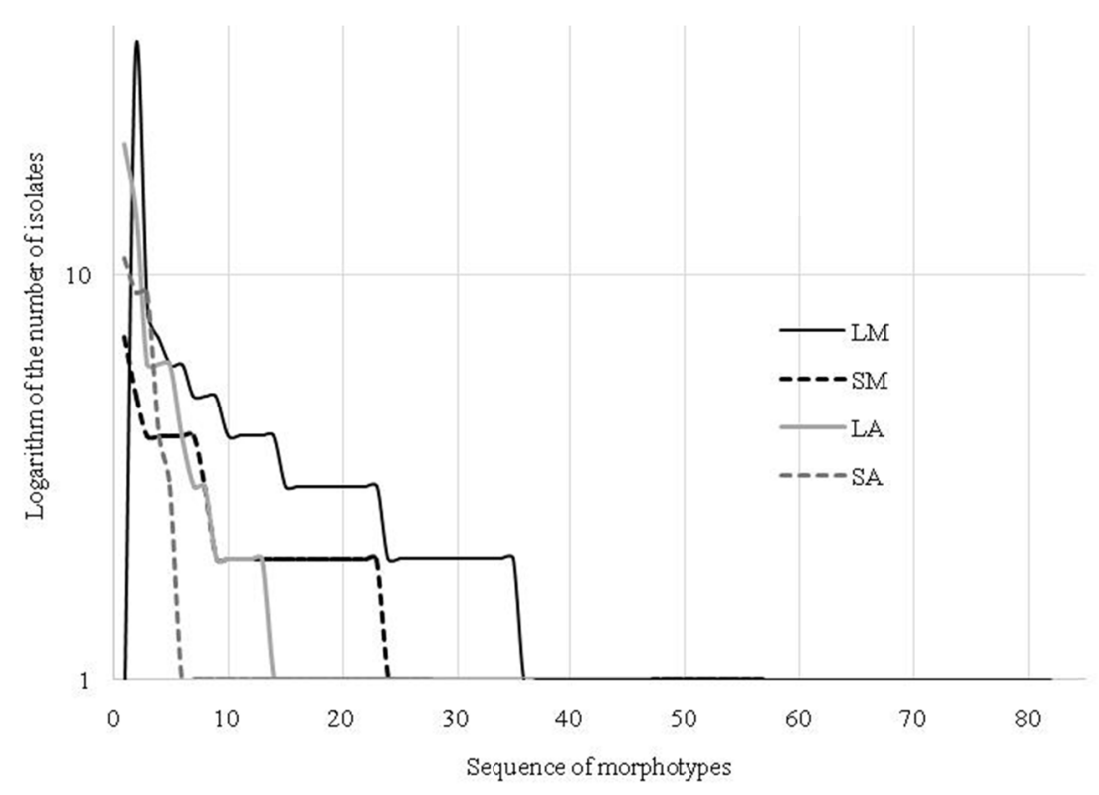

Figure 4. Curve of the dominance component of the diversity of endophytic fungi morphotypes isolated from leaves and seeds of Urena lobata cultivated in two locations in the Amazonas

Note. $\mathrm{L}=$ leaf; $\mathrm{S}=$ seed; $\mathrm{A}=$ Anori; $\mathrm{M}=$ Manaus.

\section{Discussion}

The record of a high incidence of endophytic fungi shows that these microorganisms are common in $U$. lobata when the plants develop in cultivated environments in Amazonas. This species is a source of endophytic fungi, since only one type of culture medium was used for the isolation process and a high isolation rate $(85.7 \%)$ was obtained.

The low number of genus found may be due to a possible antagonistic effect among endophytic fungi that compete for the same habitat. Thus the occurrence and dominance of certain genera may have caused the low frequency of others (Vieira et al., 2012). The endophytic fungi community was more diverse in Manaus, most probably because it was an experimental farm, where there were many other cultures nearby and where the species had already been cultivated. In Anori, the area was more uniform because it was a pasture with a lower occurrence of plant species and was used for the first time for the cultivation of the species.

The predominance of Colletotrichum in the leaves is in agreement with other observations. This genus has already been isolated as an endophyte in Virola michelli, a typical Amazonian medicinal plant used to combat skin infections (Carvalho et al., 2016). Also found on the leaf of the ornamental plant Ixora coccinia (Vieira 2012), on leaves and roots of Annona spp. (Silva, Silveira, \& Cavalcante, 2006) and leaf and stem of Gossypium sp. (Vieira, 2011).

Curvularia was isolated exclusively from seed. This corresponds to a study carried out with cotton (Gossypium L.), belonging to the same botanical family of the Malva, Malvaceae, where this genus appeared as an endophyte most frequently associated with seed (Vieira, 2011). This genus is also reported in leaves of shrub ornamental plant and forest species (Vieira et al., 2012; Freire et al., 2015). It is also mentioned as a pathogen in seeds of native forest species (Seneme et al., 2012, Medeiros et al., 2016). It is transmitted from seed to plant, causing leaf spotting in forage plantlets (Santos et al., 2014). Which means that this fungus can translocate to the leaves, remain as an endophyte, and possibly at a given moment, due to adverse conditions of the environment for the plant, to manifest causing symptoms of disease.

Fusarium was found predominantly in seeds, a result similar to that found in the isolation of endophytic fungi from several organs of Eremanthus erytropappus in which this genus of fungi colonized only the seeds (Magalhães et al., 2008). It is a pathogenic genus that is often found as endophyte (Banhos et al., 2014). There are reports of Fusarium as a pathogen in seed (Seneme, Possamai, Vanzolini, \& Martins, 2012) and as endophytic in leaf (Freire et al., 2015). 
The genus Cochliobolus presented only one isolate in Anori. Cochliobolus australiensis e C. lunatus was found in low frequency of colonization as endophytes in leaves and not found in seeds of Bauhinia forficata, a medicinal plant native to South America (Bezerra et al., 2015). This low frequency indicates momentary colonization, that is, this fungus may not be a natural endophyte, but an epiphyte or even a plant pathogen that attempts to colonize plant tissue transiently (Banhos et al., 2014).

Pestalotiopsis appeared only in Manaus. This can be explained by the influence of several factors, such as: age of the collected plant species, once the field of Manaus was sown six months before the Anori field; differences in the nutritional supply of the host tissue, as no soil correction or fertilization or irrigation was performed in any of the fields; and variability of microclimatic conditions such as relative air humidity and light exposure intensity (Petrini, 1991; Vieira et al., 2011).

Phomopsis appeared in both plant organs and in both cultivation sites more frequently than the other genus found. This genus, as endophyte, was also the most frequent and predominantly found in stems, followed by $E$. erytropappus leaves and seeds, being considered as generalist (Magalhães et al., 2008).

Symptoms of disease caused by Phomopsis sp. in experimental field of malva seed production in Manaus, and that after a period the symptoms disappeared without application of any control method (Bentes et al., 2017). This suggests that this endophytic fungus, in this culture, can become pathogenic and return to being endophytic due to environmental conditions in the host, and consequently in the fungus (Schulz \& Boyle 2005).

Among the endophytic fungi associated with malva identified in this study, there are those that according to the literature, produce bioactive compounds with biocontrol capacity. Pestalotiopsis produces phenolic compounds, isopestacin, diterpenoid taxol, with antifungal, antimicrobial and anticancer actions, respectively (Strobel et al., 1997, 2002; Li et al., 2008). This genus also produces compounds with antioxidant and phytotoxic activities, presenting an inhibitory potential of the germination and development of weeds in the Amazon (Strobel et al., 2002; Santos et al., 2008).

Phomopsis produces the bioactive compounds isopestacin and lactones (Strobel et al., 2002). Colletotrichum, Phomopsis and Fusarium were the most frequent genus isolated as endophytic from Annona spp. and efficiently promoted seedling plant growth of Annona squamosa (Silva et al., 2006).

The same genus isolated as endophytes were cited as phytopathogens, indicating the need to study the effects of agronomic factors such as soil fertility, spacing and irrigation on crop development and productivity. A plant in stress condition, due to adverse environmental conditions, may become susceptible to pests and diseases andan unfavorable environment for the plant/host and favorable to the microorganism/pathogen provides the appearance of the disease in the field.

\section{Conclusion}

Urena lobata hosts a diverse community of endophytic fungi.

The greatest richness was found in Malva leaves cultivated in Manaus.

The diversity of endophytes was higher in the plants cultivated in the municipality of Manaus.

The colonization of the endophytes was higher in the leaves than in the seeds, regardless of the place of cultivation and higher in Manaus than in Anori, regardless of the type of plant organ.

Among the six genus identified, Curvularia and Fusarium demonstrated preference for colonization in seeds, while Colletotrichum for leaves; Pestalotiopsis were limited to the occurrence in Manaus and Cochliobolus in Anori.

The similarity was greater between plant organs than at the cultivation sites, which indicates the coevolution of these fungi to the host, the result of a balanced mutual or antagonistic interaction.

\section{References}

Banhos, E. F., Souza, A. Q. L., Andrade, J. C., Souza, A. D. L., Koolen, H. H. F., \& Albuquerque, P. M. (2014). Endophytic fungi from Myrcia guianensis at the Brazilian Amazon: Distribution and bioactivity. Brazilian Journal of Microbiology, 45(1), 153-162. https://doi.org/10.1590/S1517-83822014005000027

Bentes, J., Pereira, H., Mendes, A., Castro, A., \& Cunha, A. (2017). Espaçamento para produção de sementes de malva (Urena lobata L.) em terra firme na região de Manaus-AM. Amazonian Journal of Agricultural and Environmental Sciences, 60(2), 141-146. Retrieved from http://periodicos.ufra.edu.br/index.php/ajaes/ article/view/2288 
Bernett, H. L., \& Hunter, B. B. (1972). Illustrated Genera of Imperfect Fungi (3rd ed.). Burgess Publishing Company.

Bezerra, J. D. P., Nascimento, C. C. F., Barbosa, R. N., Silva, D. C. V., Svedese, V. M., Silva-Nogueira, E. B., ... Souza-Motta, C. M. (2015). Endophytic fungi from medicinal plant Bauhinia forficata: Diversity and biotechnological potential. Brazilian Journal of Microbiology, 46(1), 49-57. https://doi.org/10.1590/ S1517-838246120130657

Carvalho, J. M., Paixão, L. K. O., Dolabela, M. F., Marinho, P. S. B., \& Marinho, A. M. R. (2016). Phytosterols isolated from endophytic fungus Colletotrichum gloeosporioides (Melanconiaceae). Acta Amazonica, 46(1), 69-72. https://doi.org/10.1590/1809-4392201500072

Crane, J., \& Acuna, J. (1945). Effect of planting rate on fiber yield de Urena lobata L. as compared with kenaf Hibiscus Cannabinus L. Journal of the American Society of Agronomy, 37(4). https://doi.org/10.2134/ agronj1945.00021962003700040001x

Ellis, M. B. (1971). Dematiaceous Hyphomycetes. Commonwealth Mycological Intitute, England.

Freire, K. T. L. S., Araújo, G. R., Bezerra, J. D. P., Barbosa, R. N, Silva, D. C. V., Svedese, V. M., ... Souza-Motta, C. M. (2015). Fungos endofíticos de opuntia Ficus indica (L.) Mill. (Cactaceae) sadia e infestada por Dactylopius opuntiae (Cockerell, 1896) (Hemiptera: Dactylopiidae). Gaia Scientia, 9(2), 104-110. Retrieved from http://www.periodicos.ufpb.br/index.php/gaia/article/view/24517

Hammer, Ø., Harper, D. A. T., \& Ryan, P. D. (2001). PAST: Paleontological Statistics Software Package for Education and Data Analysis. Palaeontologia Electronica, 4(1), 9. Retrieved from http://folk.uio.no/ ohammer/past

Homma, A. K. O. (1998). A civilização da juta na Amazônia-Expansão e declínio (Reprinted from Amazônia: Meio Ambiente e desenvolvimento agrícola, pp. 33-60).

Homma, A. K. O. (2012). Extrativismo vegetal ou plantio: Qual a opção para a Amazônia? Estudos Avançados, 26(74), 167-186. https://doi.org/10.1590/S0103-40142012000100012

Li, L., Sattler, I., Deng, Z., Groth, I., Walther, G., Klaus-Dieter, M., ... Lin, W. (2008). A-seco-oleane-type triterpenes from Phomopsis sp. (strain HKI0458) isolated from the mangrove plant Hibiscus tiliaceus. Phytochemistry, 69, 611-517. https://doi.org/10.1016/j.phytochem.2007.08.010

Maciel, A. C. (2015). Tendências do cultivo da Malva (Urena lobata L.) por agricultores familiares em Manacapuru-AM (Unpublished master's thesis, Universidade Federal do Amazonas, Brasil).

Magalhães, W. C. S., Missagia, R. V., Costa, F. A. F., \& Costa, M. C. M. (2008). Diversidade de fungos endofíticos em candeia Eremanthus erythropappus (DC.)MacLeish. Cerne, 14(3), 267-273.

Magurran, A. E. (1988). Ecological Diversity and Its Measurement. Princeton University Press, New Jersey. https://doi.org/10.1007/978-94-015-7358-0

Martins, G. C., Ferreira, M. M., Curi, N., Vitorino, A. C. T., \& Silva, M. L. N. (2006). Campos nativos e matas adjacentes da região de Humaitá (AM): Atributos diferenciais dos solos. Ciência e Agrotecnologia, 30(2). https://doi.org/10.1590/S1413-70542006000200005

Medeiros, J. G. F., Araujo Neto, A. C., Ursulino, M. M., Nascimento, L. C., \& Alves, E. U. (2016). Fungos associados às sementes de Enterolobium contortisiliquum: Análise da incidência, controle e efeitos na qualidade fisiológica com o uso de extratos vegetais. Ciência Florestal, 26(1), 47-58. https://doi.org/ $10.5902 / 1980509821090$

Nozaki, M. H., Camargo, M., \& Barreto, M. (2004). Caracterização de Diaporthe citri em diferentes meios de cultura, condições de temperatura e luminosidade. Fitopatologia Brasileira, 29(4), 429-32. https://doi.org/ $10.1590 / \mathrm{S} 0100-41582004000400012$

Odum, E. P. (1983). Basic Ecology. Harcourt Brace College Publishers.

Paterniani, E. (2001). Agricultura sustentável nos trópicos. Estudos Avançados, 15(43), 303-326. https://doi.org/ $10.1590 / \mathrm{S} 0103-40142001000300023$

Pereira, J. O., Azevedo, J. L., \& Petrini, O. (1993). Endophytic fungi of Stylosanthes: a first report. Mycologia, 85, 362-364. https://doi.org/10.2307/3760696

Petrini, O. (1991). Fungal endophytes of tree leaves (Reprinted from Microbial ecology of leaves, pp. 179-197). 
Petrini, O., Sieber, T., Toti, L., \& Viret, O. (1992). Ecology, metabolite production and substrat utilization in endophytic fungi. Natural Toxins, 1, 185-196. https://doi.org/10.1002/nt.2620010306

Santos, G. R., Tschoeke, P. H., Silva, L. G., Silveira, M. C. A. C., Reis, H. B., Brito, D. R., \& Carlos, D. S. (2014). Sanitary analysis, transmission and pathogenicity of fungi associated with forage plant seeds in tropical regions of Brazil. Journal of Seed Science, 36(1), 54-62. https://doi.org/10.1590/S2317-1537201 4000100007

Santos, L. S., Oliveira, M. N., Guilhon, G. M. S. P., Santos, A. S., Ferreira, I. C. S., Lopes-Júnior, M. L., ... Oliveira, M. C. F. (2008). Potencial herbicida da biomassa e de substâncias químicas produzidas pelo fungo endofitico Pestalotiopsis guepinii. Planta Daninha, 26(3), 539-48. https://doi.org/10.1590/S0100-835820 08000300009

Schulz, B., \& Boyle, C. (2005). The endophytic continuum. Mycological Research, 109, 661-686. https://doi.org/10.1017/S095375620500273X

Seneme, A. M., Possamai, E., Vanzolini, S., \& Martins, C. C. (2012). Germinação, qualidade sanitária e armazenamento de sementes de canafístula (Peltophorum dubium). Revista Árvore, 36(1), 01-06. https://doi.org/10.1590/S0100-67622012000100001

Silva, R. L. O., Luz, J. S., Silveira, E. B., \& Cavalcante, U. M. T. (2006). Fungos endofíticos em Annona spp.: Isolamento, caracterização enzimática e promoção do crescimento em mudas de pinha (Annona squamosa L.). Acta Botanica Brasilica, 20(3), 649-655. https://doi.org/10.1590/S0102-33062006000300015

Souza, H. H. (2012). Ambiente e sociedade: A cadeia produtiva da malva (Urena lobata L.) no médio Solimões: Uma alternativa sustentável? (Unpublished master's thesis, Universidade Federal do Amazonas, Brasil).

Strobel, G. A., Ford, E., Worapong, J., Harper, J. K., Arif, A. M., Grant, D. M., ... Ming, W. C. R. (2002). Isopestacin, an isobenzofuranone from Pestalotiopsis microspora, possessing antifungal and antioxidant activities. Phytochemistry, 60, 179-183. https://doi.org/10.1016/S0031-9422(02)00062-6

Strobel, G. A., Hess, W. M., Li, J., Ford, E., Sears, J., Sidhu, R. S., \& Summerell, B. (1997). Pestalotiopsis guepinii, a Taxol producing Endophyte of the Wollemi Pine, Wollemia nobilis. Australian Journal of Botany, 45(6), 1073-1082. https://doi.org/10.1071/BT96094

Sudha, V., Govindaraj, R, Kathirvelu, B, Al-Dhabi, N. A., \& Duraipandiyan, V. (2016). Biological properties of Endophytic Fungi. Brazilian Archives of Biology and Technology, 59. https://doi.org/10.1590/1678-43242016150436

Sutton, B. C. (1980). The Coelomycetes. Commonwealth Mycological Intitute. England.

Vieira, P. D. S., Motta, C. M. S., Lima, D., Torres, J. B., Quecine, M. C., Azevedo, J. L., \& Oliveira, N. T. (2011). Endophytic fungi associated with transgenic and non-transgenic cotton. Mycology, 2, 91-97. https://doi.org/10.1080/21501203.2011.584390

Vieira, P. D. S., Silva, F. G., Silva, W. M. T., Cavalcanti, P. A., \& Lima, D. (2012). Primeiro registro de fungos endofíticos em folhas de Ixora coccinea L. em Pernambuco, Brasil. Revista Brasileira de Biociências, 10(1), $1-4$.

\section{Copyrights}

Copyright for this article is retained by the author(s), with first publication rights granted to the journal.

This is an open-access article distributed under the terms and conditions of the Creative Commons Attribution license (http://creativecommons.org/licenses/by/4.0/). 